\title{
Mid-Season Prediction of Wheat-Grain Yield Potential Using Plant, Soil, and Sensor Measurements
}

\author{
K. Girma, K. L. Martin, R. H. Anderson, D. B. Arnall, K. D. Brixey, \\ M. A. Casillas, B. Chung, B. C. Dobey, S. K. Kamenidou, S. K. Kariuki, \\ E. E. Katsalirou, J. C. Morris, J. Q. Moss, C. T. Rohla, B. J. Sudbury, \\ B. S. Tubana, and W. R. Raun
}

Department of Plant and Soil Sciences, Oklahoma State University, Stillwater, OK, USA

\begin{abstract}
The components that define cereal-grain yield potential have not been well defined. The objective of this study was to collect many differing biological measurements from a long-term winter wheat (Triticum aestivum L.) study in an attempt to better define yield potential. Four treatments were sampled that annually received 0, 45, 90, and $135 \mathrm{~kg} \mathrm{~N} \mathrm{ha}^{-1}$ at fixed rates of phosphorus $(\mathrm{P})\left(30 \mathrm{~kg} \mathrm{ha}^{-1}\right)$ and potassium $(\mathrm{K})$ $\left(37 \mathrm{~kg} \mathrm{ha}^{-1}\right)$. Mid-season measurements of leaf color, chlorophyll, normalized difference vegetative index (NDVI), plant height, canopy temperature, tiller density, plant density, soil moisture, soil $\mathrm{NH}_{4}-\mathrm{N}, \mathrm{NO}_{3}-\mathrm{N}$, organic carbon $(\mathrm{C})$, total nitrogen $(\mathrm{N}), \mathrm{pH}$, and $\mathrm{N}$ mineralization potential were collected. In addition, soil texture and bulk density were determined to characterize each plot. Correlations and multiple linear-regression analyses were used to determine those variables that can predict final winter wheat grain yield. Both the correlation and regression analyses suggested mid-season NDVI, chlorophyll content, plant height, and total $\mathrm{N}$ uptake to be good predictors of final winter wheat grain yield.
\end{abstract}

Keywords: NDVI, sensor, indirect measures, yield goal, yield prediction, yield potential, corn

Received 20 December 2004; accepted 7 September 2005.

Address correspondence to W. R. Raun, Department of Plant and Soil Sciences, Oklahoma State University, Stillwater, OK 74078, USA. E-mail: wrr@mail.pss.okstate. edu 


\section{INTRODUCTION}

In an attempt to better understand several selected variables that influence yield potential, a succinct literature review on each specific variable measured from a long-term winter wheat experiment is presented. The methods used for collecting data on each of the variables are also included.

\section{Leaf Color}

Leaf color charts have been used with rice (Oryza sativa L.) to determine nitrogen (N) status (Singh et al., 2002) and are related to chlorophyll meter readings (Yang et al., 2003). Aerial photographs analyzing color have been used successfully to predict sidedress $\mathrm{N}$ needs in corn (Zea mays L.) (Scharf and Lory, 2002). Crop and turfgrass color are often evaluated visually, which is a somewhat subjective measure. Leaf color charts and standardized color charts may be effective in some situations, but analyses will differ by person and cultivar. Time of year, time of day, cloud cover, etc., could alter an observation. Karcher and Richardson (2003) used digital image analysis to quantify turfgrass color. They found that digital image analysis is a reliable and objective means to evaluate turf color, but only when images are collected under equal lighting conditions. Digital photography and image analysis software have also been used to study canopy coverage in wheat (Triticum aestivum L.) (Lukina et al., 1999) and soybeans [Glycine max L. (Merr.)] (Purcell, 2000). Digital photography and image analysis may potentially help farmers determine $\mathrm{N}$ requirements in crops by determining crop color in an objective manner.

\section{Chlorophyll Meter Readings}

Leaf chlorophyll content can be closely correlated with leaf $\mathrm{N}$ content due to the location of $\mathrm{N}$, which is primarily a component of the chlorophyll molecule, in the leaf. Therefore, Wood et al. (1992) found that chlorophyll measurements correlate well with $\mathrm{N}$ concentration in the plant tissue. Many methods of $\mathrm{N}$ determination in plants exist, but most are destructive procedures. The ability to determine the chlorophyll content and the related $\mathrm{N}$ status of a plant at different stages and in conjunction with other factors would be extremely valuable in establishing how yield potential is affected by the chlorophyll content and the related $\mathrm{N}$ status.

The Minolta Soil Plant Analysis Development (SPAD-502) chlorophyll meter is one tool that enables researchers to determine chlorophyll content by measuring leaf greenness (Peterson et al., 1993). The SPAD uses a silicon photodiode to derive the ratio of transmittance through the leaf tissue at $650 \mathrm{~nm}$ compared with transmittance at $940 \mathrm{~nm}$, and a value is given based on that ratio (Schepers and Francis, 1998). To date, most of the research conducted in conjunction with the SPAD has been aimed at utilizing it as a $\mathrm{N}$-management tool. 
Research conducted in Nebraska has shown that the chlorophyll meter reading used with a sufficiency index was successful as an in-season N-management tool for irrigated corn (Zea mays L.) (Varvel et al., 1997). In-season chlorophyll meter-based treatments used with a sufficiency index were able to maintain the yield achieved with traditional fixed-timing $\mathrm{N}$ treatments while also reducing the amount of $\mathrm{N}$ applied in rice experiments conducted in the Philippines (Hussain et al., 2000). Other research with corn indicates that chlorophyll meter readings as an estimate of leaf chlorophyll content correlate with yield as accurately as leaf $\mathrm{N}$ concentrations (Schepers et al., 1992), and similar results were reported between SPAD values and wheat grain yield in India (Singh et al., 2002).

Species and variety differences will result in differing chlorophyll meter readings. Researchers with the United States Department of Agriculture (USDA) and the University of Nebraska documented considerable differences in chlorophyll meter readings between different varieties and hybrids of corn and sorghum (Peterson et al., 1993). To utilize the meter as a management tool, however, the most reliable method involves the use of $\mathrm{N}$-rich reference strips within each field. These reference strips should accurately represent the field for all factors except the $\mathrm{N}$ treatment to insure that the yield potential of the field is not limited by a lack of N (Peterson et al., 1993). The literature recommends 20 (Schepers and Francis, 1998) to 30 (Peterson et al., 1993) readings per field to establish an accurate representation; however, an independent sample experiment indicated that as few as eight averaged samples accurately represented a plot of approximately $1 \mathrm{~m}^{2}$. In corn, readings should be collected from the uppermost, fully expanded leaf at a point one-half the distance from the leaf tip to the collar, and one-half the distance between the leaf margin and the midrib (Peterson et al., 1993). After collecting average readings representing both the field and the reference strip, a sufficiency index can be calculated.

$$
\text { Sufficiency Index }(\mathrm{SI})=\frac{\text { Average reading representing field }}{\text { Average reading of N-rich reference strip }} \times 100
$$

When utilizing the chlorophyll meter as a management tool, $\mathrm{N}$ application is based on the calculated sufficiency index. For corn, a SI lower than $95 \%$ indicates an $\mathrm{N}$ deficiency and additional $\mathrm{N}$ should be added (Varvel et al., 1997). An SI of $90 \%$ was found to be more efficient when applied to rice grown in Asia (Hussain et al., 2000).

Factors affecting SPAD values include radiation differences between seasons, variety and species differences, plant and soil nutrient status (including $\mathrm{N}$ and other nutrients), and biotic and abiotic stresses (Peterson et al., 1993). Excess soil water in sub-humid regions with high-organic-matter soils has also been shown to disrupt the relationship between chlorophyll meter readings and plant N status (Dinnes et al., 2002). The chlorophyll meter has been proven to determine accurately when fertilization is needed, but is limited in that it is not able to estimate the amount of fertilizer needed (Varvel et al., 1997). 


\section{Nitrogen Availability and Active NDVI Sensors}

Nitrogen is an essential plant nutrient required for high yield. Under ideal conditions, $\mathrm{N}$ availability to the crop is one of the most critical and variable factors when predicting crop yields. Of the $\mathrm{N}$ fertilizer used for crops, only $33 \%$ is actually removed in the grain (Raun and Johnson, 2001). The use of reflectance of red and near-infrared wavelengths during early growth stages has been researched extensively; it indicates $\mathrm{N}$ status of wheat and can be used to predict potential grain yield (Raun et al., 2001; Filella et al., 1995).

Oklahoma State University (Stillwater, OK), jointly with NTech Industries (Ukiah, CA), developed the GreenSeeker Hand Held Optical Sensor. This sensor using the current algorithm has the ability to determine the amount of $\mathrm{N}$ fertilizer to apply for each $0.4 \mathrm{~m}^{2}$ area. This knowledge allows farmers to increase yield while reducing excess application of $\mathrm{N}$ fertilizer. Following extensive soil sampling, optical-sensor measurements of plants, and geostatistical analysis, it was reported that the spatial scale of $\mathrm{N}$ availability was at $<1 \mathrm{~m}^{2}$ and that each square meter needed to be treated independently (Raun et al., 1998; Solie et al., 2000; Raun et al., 2002). When N management decisions are made on areas of $<1 \mathrm{~m}^{2}$, the variability that is present at that resolution can be detected using optical sensors and treated accordingly with foliar application of N (Raun and Johnson, 2001; Solie et al., 1996; Stone et al., 1996). Remote sensing data is collected by a modified daytime-lighting reflectance sensor, which is used to estimate early-season plant $\mathrm{N}$ uptake. The estimate is based on a relationship between NDVI and plant $\mathrm{N}$ uptake between Feekes physiological growth stage 4 (leaf sheaths lengthen) and stage 6 (first node of stem visible) (Solie et al., 1996; Stone et al., 1996).

\section{Plant Height}

Plant height factors have not recently been studied to a great extent. The difficulty of utilizing plant height as a factor to better predict yield potential is that it must be coupled with some other parameter that takes into account the spatial variability of the plants. Mallarino et al. (1999) noted that it is possible that a variable is not related to the yield in a field because the range of variation within that field is above or below the range in which it influences yields. However, Machado et al. (2002) found that plant height explained 61\% of the variation in grain yield in corn. Studies conducted at Iowa State University showed that in three of five corn fields, a strong relationship was found between yield and height (Mallarino et al., 1999). Current work on corn at Oklahoma State University suggests that plant height and NDVI can be reliable predictors of forage biomass and final grain yield on a by-plant basis. Recognizing the difference between corn and wheat, but acknowledging the concept employed here, plant height in wheat will likely play an effective role in predicting 
final grain yield, but may be improved by adding another dimension of plant characteristics.

\section{Canopy Temperature}

Early work by Millard et al. (1978) showed a correlation between canopy temperature and plant water stress. Remotely sensed infrared canopy and hand-held infrared thermometers provide a new, easy, non-destructive method for measuring canopy temperature (Rashid et al., 1999; Nielson and Halvorson, 1991). Canopy temperature is used as a factor to predict water stress in several crops as a screening tool for breeding drought-tolerant varieties, and canopy temperature depression (CTD) is used as a potential indirect criterion for yield (Rashid et al., 1999; Clawson et al., 1989; Fisher et al., 1998).

A modified crop water-stress index that includes environmental factors such as canopy temperature was proposed by Clawson et al. (1989). A study by Rashid et al. (1999) reported grain yield variation related to plot-to-plot differences in canopy temperature under water-stressed conditions. For spring wheat, a positive correlation between grain yield and cooler canopies was found (Fisher et al., 1998).

\section{Seeding Density}

Seeding density affects grain yields and plant density (McLeod et al., 1995). In addition, high seeding density can result in higher grain yields and plant density than low seeding density (Johnson et al., 2001). High seeding density has been reported to improve grain yield of wheat under conventional cropping systems (Conventry et al., 1993; Rurnett et al., 2003). Stougaard and Xue (2003) found that high seeding density increased yield $12 \%-18 \%$ when compared with low seeding density in Montana. Work in Canada showed that a $60 \mathrm{~kg} \mathrm{ha}^{-1}$ seeding rate resulted in a $61 \%$ higher plant density than a $30 \mathrm{~kg} \mathrm{ha}^{-1}$ seeding rate (McLeod et al., 1995). High seeding density can control weed biomass and reestablishment of weeds in ensuing seasons and can compensate for poor plant establishment (Rurnett et al., 2003).

\section{Tillering}

Tillering is the product of added stem formation on the mainstem or crown of the plant. According to Peterson et al. (1982), the ability of a plant to produce tillers can play a role in wheat plant survival because the plant can produce a secondary crown, which could protect the plant from death if the main crown were to be damaged. 
At three of four locations, Flowers et al. (2001) found a relationship between NIR, NDVI, and tiller density to be significant. It has also been found that tiller density may be used to give an $\mathrm{N}$ recommendation for application during the growing season. Flowers et al. (2003) found that they could use NIR sensing during Feekes physiological growth stage 3 to predict tiller density and subsequent $\mathrm{N}$ recommendation using a soft red winter wheat variety.

\section{Soil Moisture}

Several studies have shown the importance of optimum soil moisture in wheat production. Robinson et al. (1999) used a crop model and historical climate records (1960-1993) to produce a long-term record of yield and grain protein responses to $\mathrm{N}$ fertilizers. The study proved that fertilizer $\mathrm{N}$ application was most profitable if used when measurements indicate that the plant-available soil moisture content before sowing is above average. Another study by Major et al. (1988) was conducted to investigate yield and yield components of winter wheat as affected by soil water and $\mathrm{N}$ at five locations. It was confirmed that moisture stress was the most limiting factor in the Great Plains. The increase in wheat yield under optimum soil moisture was attributed to increased number of spikes. Hoogenboom et al. (1994) noted that the processes affected by water stress include vegetative development; reproductive development; photosynthesis; biomass partitioning; pod and seed addition; grain, ear or head addition; leaf area growth and expansion; root growth; transpiration; senescence; and various other processes.

Precipitation is the source of all soil moisture in rainfed cropping systems (Heinmann et al., 2002); thus, crop production may be susceptible to water stress once soil water drops below a critical level caused by fluctuating rainfall. Using computer-simulation models, crop yield can be predicted as a function of weather and soil conditions; thus, data on rainfall and precipitation are one of the key inputs (Heinmann et al., 2002). Using historical data on monthly rainfall and monthly evaporation, weekly and daily rainfall and simulated weekly soil moisture, Huda (1994) developed simple risk-management principles in evaluating alternate strategies to increase and stabilize wheat yield in low-rainfall areas of southern Australia. The study by Arora and Gijri (1998) on the evaluation of a crop growth-water balance model for analyzing wheat responses to climate and a water-limited environment suggested that computer models can be applied for optimizing water use at the field scale.

\section{Soil Color and Soil Texture}

Soil color is important because it is related to organic-matter content, climate, soil drainage, and soil mineralogy (Troeh and Thompson, 1993). The Munsell Soil Color Chart is used to determine and report soil color (Munsell, 1988). 
This standardized system uses color chips to enable one to determine the hue, value, and chroma of soils.

Soil texture is recorded as the ratio of the three soil components (sand, silt, clay) based on their physical dimensions. This ratio is most frequently presented as a textural triangle, which readily enables one to determine the basic soil type (Sparks, 2003). Soil texture contributes significantly to physical properties (including pore structure, aeration, and water drainage) (Brady and Weil, 2002) and to chemical properties [including permanent and $\mathrm{pH}$-dependent charge, cation exchange capacity (CEC), and soil organic material and nutrient composition] (Sylvia et al. 1999). A table comparing the particle-size limits in particle-size classification used by four different agencies has recently been republished (Jones, 2001). Soil-texture determinations are most often performed using the pipette and the hydrometer methods (Gee and Bauder, 1986).

\section{Soil Bulk Density}

Bulk density affects plant growth through its effect on soil strength and soil porosity (Chan, 2002). Increased bulk density increases soil strength and reduces soil porosity. Both of these factors limit root growth at some critical value. The mechanical effects of high bulk density are the direct effects on root growth. The indirect effects are a reduction in aeration and soil water conductivity and retention (Lampurlanés and Cantero-Martínez, 2003). Lower bulk density means less soil mass for a given depth of soil, and therefore, lower CEC and fewer nutrients.

Droogers and Bouma (1996) compared four fields that were under different management for 70 years. Two were cultivated with organic farming and two with conventional farming. The loam soil in the conventional fields had a higher bulk density $\left(1.61 \mathrm{Mg} \mathrm{m}^{-3}\right)$ than the organic fields $\left(1.50 \mathrm{Mg} \mathrm{m}^{-3}\right)$ and $7 \%$ lower simulated potato yield. Ishaq et al. (2001) observed that when subsoil bulk density was artificially increased from 1.65 to $1.93 \mathrm{Mg} \mathrm{m}^{-3}$, the grain yield of the next crop decreased by $38 \%$. This study showed the negative effects of subsoil compaction on crop yield. It also showed that the effect of compaction is reduced over time, possibly because the soil structure improves. Lal and Ahmadi (2000) reported that tillage treatment affects soil bulk density but not grain yield in a consistent way season after season. However, looking at the means of 11 seasons for one site, there is an inverse relationship between bulk density and grain yield. The soil with the highest bulk density $\left(1.31 \mathrm{Mg} \mathrm{m}^{-3}\right)$ had $13 \%$ less yield than the soil with the lowest bulk density $\left(1.25 \mathrm{Mg} \mathrm{m}^{-3}\right)$.

\section{Soil pH}

Soil $\mathrm{pH}$ is responsible for various soil chemical reactions and processes. According to Sparks (2003), acid rain is one of the major sources of low pH. Acid 
rain is a result of a reaction of atmospheric emission of industrial gases, sulfur dioxide $\left(\mathrm{SO}_{2}\right)$, and nitrogen dioxide $\left(\mathrm{NO}_{2}\right)$ which form sulfuric and nitric acid, respectively. Evans (1991) observed that a decrease in soil pH in Australian soils was largely influenced by agricultural practices.

At low $\mathrm{pH}$, phosphorus $(\mathrm{P})$ availability may be reduced and calcium $(\mathrm{Ca})$ and magnesium $(\mathrm{Mg})$ levels are likely to be inadequate. Aluminum ( $\mathrm{Al}$ ) hydrolyses under acidic conditions and forms hydroxyl aluminum, which can be fixed on the cation-exchange capacity (CEC). Hydroxyl aluminum is said to be non-exchangeable, which reduces the CEC of clays and soils (Sparks, 2003). This reduction may result in deficiencies of these nutrients, restricting optimal crop production.

\section{Nitrogen Mineralization Potential}

Many factors are involved in the process of $\mathrm{N}$ mineralization, including soil moisture, temperature, texture, structure, aeration, microbial biomass, and the substrate chemical constituency (Ringuelet and Bachmeier, 2002; Drury et al., 2003; Vigil and Kissel, 1991). All of these factors interact ultimately to govern the amount of $\mathrm{N}$ available via mineralization from year to year. Rassmussen et al. (1998) suggests management is the primary factor responsible for regulating $\mathrm{N}$ dynamics in agricultural systems and should be taken into consideration when estimating $\mathrm{N}$ fertilizer needs. They found the highest $\mathrm{N}$ mineralization potential under uncultivated pasture, with increasing rates of $\mathrm{N}$ application, reduction in tillage intensity, and a higher frequency of cropping as determinant factors enhancing the mineralizable pool of organic $\mathrm{N}$ in the cultivated fields they studied.

A study from Canada conducted by Walley et al. (2002) assessed the relationships between soil-N availability indices (SNAI), yield, and plant $\mathrm{N}$ uptake in wheat from fields positioned at various locations on the landscape. The SNAIs included two- and 16-week aerobic incubations, $\mathrm{NO}_{3}$ sorption onto anion-exchange membranes, and $\mathrm{N}$ extraction and hydrolysis with hot potassium chloride $(\mathrm{KCl})$ in a laboratory under optimal microbial temperature and moisture regimes. These researchers reported a slight correlation among all SNAIs with yield and (for the most part) with plant $\mathrm{N}$ uptake. The best variability explained was 40\% (Malhi et al., 1992). These researchers noted that SNAIs must be combined with field-scale variability in order to predict accurately the size of the potentially mineralizable-N pool in glacial till, semi-arid agricultural systems.

\section{Organic Carbon and Total Nitrogen in Soils}

It is common to find a net mineralization of $\mathrm{N}$ in soil when residuals are added that have high carbon (C)-to-N ratios (Groffman, 1999). It has been found that a 
$\mathrm{C}: \mathrm{N}$ ratio of 25 results in a highly stable product, good fertilizer value, and low potential for possible environmental pollution (Ndegwa and Thompson, 2000). However, looking at the $\mathrm{C}: \mathrm{N}$ ratio may not result in an accurate prediction of resulting mineralization or immobilization (Risasi et al., 1999).

With decreasing particle size, mineralization of $\mathrm{C}$ and $\mathrm{N}$ decreased, resulting in a more stable C:N ratio (Rovira and Vallejo, 2002). In one experiment, $\mathrm{C}$ was added with the expectation of increased biomass $\mathrm{C}$ and $\mathrm{N}$ along with a decrease in inorganic $\mathrm{N}$. The additions of $\mathrm{C}$ and $\mathrm{N}$ to the soil environment resulted in a far more complex than a simple $\mathrm{C}: \mathrm{N}$ ratio (Groffman, 1999). Resulting changes in $\mathrm{C}$ and $\mathrm{N}$ are effected by multiple factors. These factors include but are not limited to form of $\mathrm{C}$, form of $\mathrm{N}, \mathrm{C}: \mathrm{N}$ ratio, microbial activity, soil texture, age of environment, soil nutrients present, and tillage practices (Cote et al., 2000).

\section{Statistical Parameters}

Soil, equipment, seed, and environmental factors all affect wheat-stand establishment. Oklahoma farmers commonly expect $77 \%$ of their viable seed to emerge; however, research has shown that the percentage emergence may be closer to 57\% (Stockton et al., 1996). Stockton et al. (1996) found that stands in individual fields ranged from less than $30 \%$ emergence to better than $80 \%$. Weisz et al. (2001) reported that as plant stand or tiller density increases, grain yield tends to increase and the variation within the field decreases. These studies show the presence of stand variability in wheat fields and are an indication of the need to detect this variability to predict yield.

Coefficient of variation (CV) is defined as the standard deviation divided by the mean (Steel et al., 1997). Steel et al. (1997) described CV as a quantity of use to the experimenter in evaluating results from different experiments involving the same unit of measurement but that may have been conducted by different persons. Little and Hills (1978) suggest that CVs can be used to compare experiments involving different units of measurement and/or plot sizes. The CV is a relative measure of variation and varies with every comparison, depending on what is considered large or small, and only experience with similar data can determine its magnitude (Steel et al., 1997).

In an evaluation of 62 wheat field research projects, Taylor et al. (1997) observed that mean yield and CV are negatively correlated. This work also showed that $\mathrm{CVs}$ decrease with corresponding decreases in plot size. Washmon et al. (2002) suggested that if within-field CVs could be predicted, the potential response to added nutrients may also be established and in-season nutrient additions adjusted accordingly. Furthermore, mid-season CV of a field can be equated to the response index, which is currently used by various researchers to determine topdress fertilizer needs. Lukina et al. (2000) observed that as the vegetation coverage increase, the $\mathrm{CV}$ of spectral radiance (NDVI) values 
decreases. This report suggests that the CV of NDVI readings could be used to estimate stand density. Raun et al. (2001) showed that NDVI values from mid-season sensor readings could be used to predict yield. Combining NDVI and $\mathrm{CV}$ may result in improved prediction of yield potential and improved mid-season prediction of the response to applied fertilizer $\mathrm{N}$.

\section{MATERIALS AND METHODS}

Data from a long-term (30-year-old) winter wheat experiment established the Agronomy Research Station in Stillwater, OK were used for this report. The soil at the experimental site is a deep, well-drained Kirkland Silt Loam [fine, mixed, thermic Udertic Paleustolls (Lukina et al., 2001)]. The soil texture of this site was loam (32.36\% sand, $20.28 \%$ clay, and $47.36 \%$ silt). The experiment employed a randomized-complete-block experimental design with four replications. The treatments used for this report were $0,45,90$, and $135 \mathrm{~kg} \mathrm{~N} \mathrm{ha}^{-1}$ with fixed levels of 29 and $37 \mathrm{~kg} \mathrm{ha}^{-1} \mathrm{P}$ and $\mathrm{K}$, respectively. One additional control plot (no fertilizer) was also included. Plot size was $12.2 \times 18.3 \mathrm{~m}$. Ammonium nitrate (34-0-0), triple super phosphate $(0-20-0)$, and potassium chloride $(0-0$ $50)$ were broadcast and incorporated prior to planting. Winter wheat was planted in $25 \mathrm{~cm}$ rows at a seeding rate of $67 \mathrm{~kg} \mathrm{ha}^{-1}$ and grown under conventional tillage (disk incorporation of wheat-straw residues following harvest and prior to planting).

Leaf color was measured from four randomly selected shoots within each plot at Feekes physiological growth stages 5 (stem elongation), 7 (two nodes), and 10 (late boot stage) using the color chart developed at the International Rice Research Institute (see http://www.irri.org). Similarly, chlorophyll readings were collected using a Minolta 502 SPAD meter from 15 randomly selected, fully extended leaves in each plot at Feekes physiological growth stages 5, 7, and 10. Sensor readings were collected from each plot using a GreenSeeker handheld sensor developed by NTech Industries that measures NDVI (Crop TRAK, Plainfield, IL). Canopy temperature was measured at five randomly selected positions within each plot using a handheld infrared thermometer. Similarly, plant height was determined by measuring the height of 15 randomly selected extended leaves in each plot.

Seeding density was determined by calculating the number of seeds per kilogram planted on each plot. Tiller density was evaluated by counting the number of tillers in 10 plants in six randomly selected rows. The tiller density was evaluated at Feekes physiological growth stages 5, 7, and 10. The values reported in Table 2 represent the average number of tillers per plant.

Percent soil moisture was determined within each plot at Feekes physiological growth stages 5 and 7 from depths of $0-15,15-30$, and 30-46 cm (0-6, 6-12, and 12-18 in) using weights of wet and dry soil samples to calculate the percentage moisture content. 
Soil color was determined by comparing the dry soil color to the Munsell soil color chart under full sunlight. The soil texture was determined using a hydrometer (Sparks, 2003) on one sample collected from each plot.

The bulk density was measured using soil cores sampled from the different treatments (core method) (Blake and Hartage, 1986). Four cores were taken from each of the treatments at a depth of $0-15 \mathrm{~cm}$. The bulk-density values were calculated as the average of four samples taken from each of the treatments.

Nitrogen mineralization was studied using the method described by Stanford and Smith (1972). Four $20 \mathrm{~g}$ dry-weight equivalent (DWE) aliquots of each bulked field moist-soil sample was brought to $55 \%$ water-filled pore space and incubated at $25^{\circ} \mathrm{C}$ in a dark room at constant temperature in $100 \mathrm{~mL}$ specimen cups. Samples were weighed weekly to maintain moisture content and supplied with de-ionized water accordingly. Every $30 \mathrm{~d}$, a set of subsamples was removed and analyzed for $\mathrm{NH}_{4}-\mathrm{N}$ and $\mathrm{NO}_{3}-\mathrm{N}$ using a Lachat Quickchem Autoanalyzer (Milwaukee, WI). The following nonlinear regression equation described by Smith et al. (1980) was used to calculate the mineralizable pool of organic $\mathrm{N}\left(\mathrm{N}_{\mathrm{o}}\right)$ and the first-order rate coefficient $(\mathrm{k})$ :

$$
\mathrm{N}_{\mathrm{m}}=\mathrm{N}_{\mathrm{o}}[1-\exp (-\mathrm{kt})]
$$

where $\mathrm{N}_{\mathrm{m}}=$ amount of $\mathrm{N}$ mineralized at a specific time ( $\left.\mathrm{t}\right)$. All results reported are the mean of four replications and are on a moisture-free basis. Moisture was determined after drying at $95^{\circ} \mathrm{C}$ for $24 \mathrm{~h}$.

From each plot, 15 soil cores from a depth of $0-15 \mathrm{~cm}$ were collected. Soil samples were air-dried at ambient temperature and ground to pass a 20mesh screen. Samples were extracted using $2 \mathrm{M} \mathrm{KCl}$ (Bremner, 1965) and analyzed for $\mathrm{NH}_{4}-\mathrm{N}$ and $\mathrm{NO}_{3}-\mathrm{N}$ using an automated-flow injection analysis system (Lachat Quickchem Autoanalyzer). Total N and organic C were determined using a Carlo-Erba NA 1500 dry combustion analyzer (Schepers et al., 1989). Soil $\mathrm{pH}$ was determined by collecting $10 \mathrm{~g}$ of soil from each plot using a 1:1 soil:water ratio from the $0-15 \mathrm{~cm}$ soil depth.

The correlation coefficients between final grain yield and plant and soil variables provided a good basis for deciding which variables to consider. The challenge of identifying suitable variables to explain final grain yield, however, is evaluating the contribution of the variables jointly. A multiple linearregression approach was used to address this issue. Since there were several variables correlated with final grain yield, a stepwise regression was carried out using two criteria, namely, $\mathrm{R}^{2}$ and $\mathrm{C}_{p}$ [these criteria are presented in detail in Mallows (1973) and Kutner et al. (2004)]. Decisions for adding and removing variables were made using two significant levels $(0.15$ and 0.10$)$. Once the variables were selected, models containing various numbers of predictor variables were tested for their ability to recover the variability in final grain yield based on the F-test and the partial regression sum of squares for each variable. 


\section{RESULTS AND DISCUSSION}

\section{Leaf Color, Chlorophyll, and NDVI}

Mean leaf color, chlorophyll meter readings (SPAD), and NDVI measurements by treatment are reported in Table 1. In general, all three were well correlated with final wheat-grain yield at Feekes physiological growth stages 5, 7, and 10. However, there was a tendency for all to be better correlated with final grain yield at Feekes physiological growth stage 7 (simple correlation coefficients, $r>$ 0.85 ). The NDVI readings were better correlated with leaf color-chart readings than SPAD readings. This result would suggests some disparity in the information collected within the NIR band (NDVI uses reflectance at 650 and $770 \mathrm{~nm}$, while the Minolta SPAD unit measures transmittance at 650 and $940 \mathrm{~nm}$ ).

Because of the ease associated with collecting NDVI readings using handheld sensors, and because the current GreenSeeker sensor averages readings from the entire surface area (versus one spot on a leaf using the chlorophyll meter), NDVI readings are vastly superior to chlorophyll meter readings and/or

Table 1

Response of NDVI, CV (from NDVI) and leaf color chart readings as influenced by treatment in long-term fertility experiment \#222, Stillwater, OK, 2004

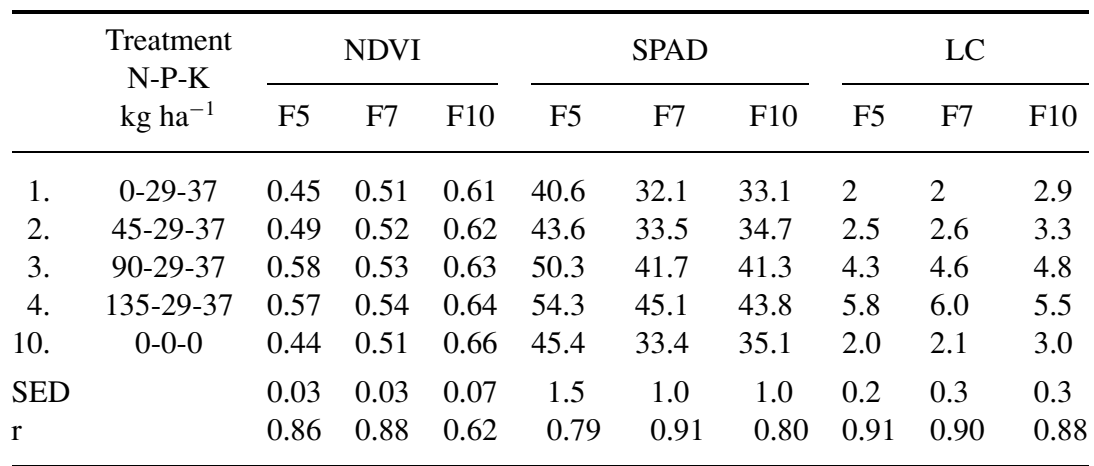

$\mathrm{N}, \mathrm{P}$, and $\mathrm{K}$ applied preplant and incorporated as ammonium nitrate $(34 \% \mathrm{~N})$, triple superphosphate $(20 \% \mathrm{P})$, and potassium chloride $(49 \% \mathrm{~K})$.

$\mathrm{CV}$ - coefficient of variation.

NDVI—normalized difference vegetative index.

SPAD—soil plant analysis development developed by Minolta Co. as an indirect measure of chlorophyll.

LC-leaf color chart, (range of 1-5).

F5-Feekes growth stage 5 (leaf sheaths strongly erected).

F7-Feekes growth stage 7 (second node of stem visible).

F8-Feekes growth stage 10 (in boot).

SED—standard error of the difference between two equally replicated means.

$\mathrm{r}$ - simple correlation coefficient for each variable versus final grain yield. 
leaf color charts. Furthermore, because readings are calibrated (repeatable over space and time and not influenced by ambient light or temperature), it is likely that their use in agronomic research will increase substantially over the next few years.

\section{Plant Height and Canopy Temperature}

As plant height increased, so did wheat grain yield [this experiment included only one variety (Table 2)]. Plant height was highly correlated with final grain yield at all growth stages (simple correlation coefficients ranged from $r=0.73$ to 0.90 ) and tended to increase as the season progressed. This result makes sense because measuring the most fully extended leaf at Feekes physiological growth stage 5 is somewhat subjective, while at later stages of growth, the main stem and associated leaves are more easily identifiable.

Canopy temperature was not highly correlated with wheat-grain yield at any stage of growth. Canopy temperature was lower where $\mathrm{N}$ fertilizer was applied (treatments 2, 3, 4) and higher under no $\mathrm{N}$ (treatments 1 and 10) (Table 2). This result was likely due to the increased foliage in the $\mathrm{N}$-fertilized plots and increased soil coverage, thus soil temperatures decreased as a result of increased light interception by the growing plants. However, there was not much difference among treatments using canopy temperature, probably because there were simply no large measurable differences, or because the IR thermometer used was not highly sensitive.

\section{Tillering}

Similar to other variables included in this study, tillers were well correlated with final grain yield at all hree growth stages $(r=0.55,0.89$, and 0.24 , respectively). Further, the relationship was much stronger at Feekes 7. Discernable differences were much more difficult to detect at Feekes 10, largely due to the tiller abortion that takes place between jointing and boot stages (Table 2).

\section{Soil Moisture}

Mean soil moisture values determined at Feekes physiological growth stages 5 and 7 are reported by depth and treatment in Table 3 . Soil moisture in the surface 0-15 and 15-30 cm depths at Feekes physiological growth stage 5 was negatively correlated with wheat-grain yield $(r=-0.68$ and -0.53 , respectively). By Feekes physiological growth stage 7, no relationship between soil moisture and wheat-grain yield was found at any depth. Under rainfed conditions where moisture is generally limiting, a negative correlation between surface 


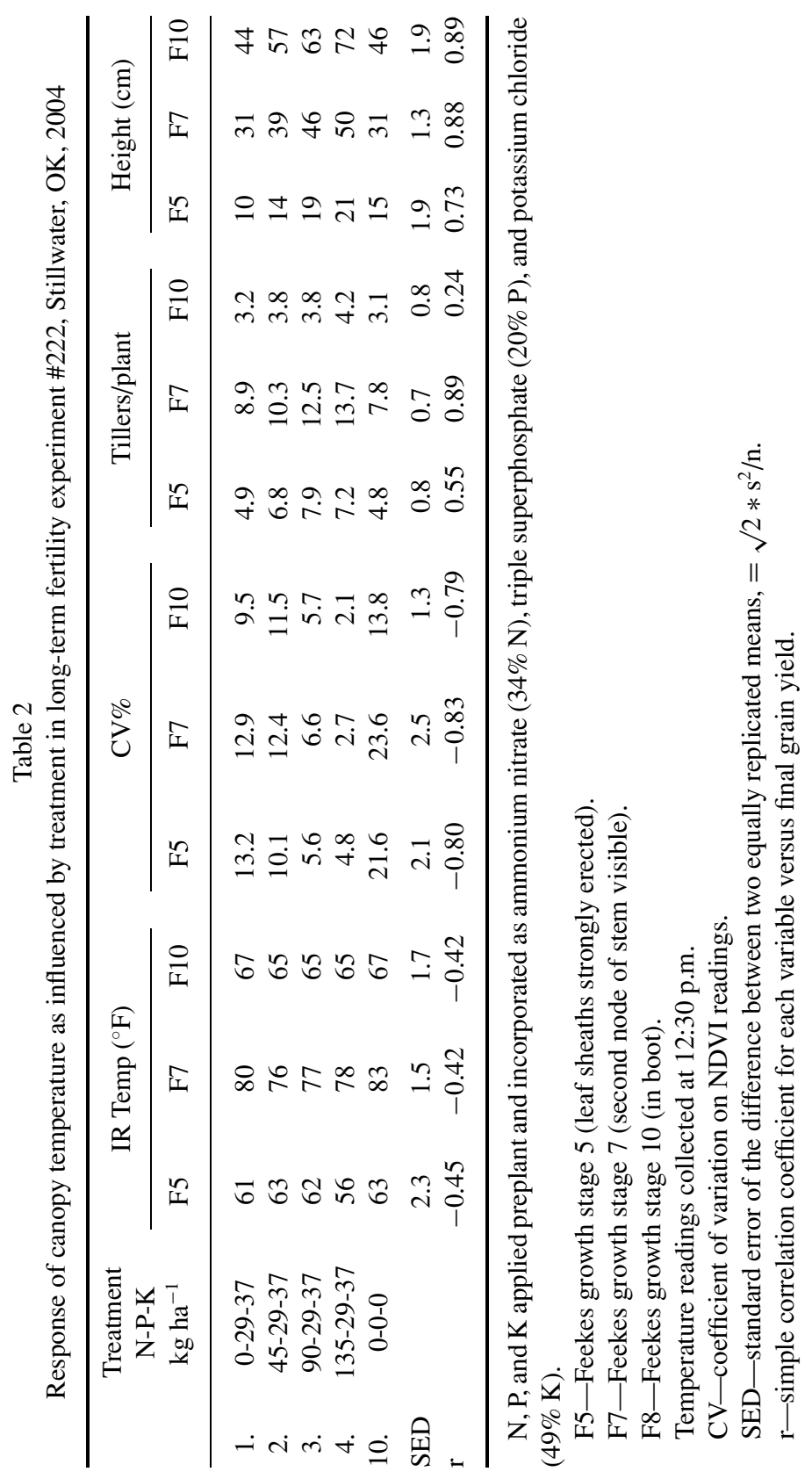


Table 3

Soil moisture content at different depths in long-term fertility experiment \#222, Stillwater, OK, 2004

\begin{tabular}{|c|c|c|c|c|c|c|c|c|}
\hline & \multirow{3}{*}{$\begin{array}{l}\text { Treatment } \\
\text { N-P-K } \\
\mathrm{kg} \mathrm{ha}^{-1}\end{array}$} & \multicolumn{7}{|c|}{$\begin{array}{l}\text { Soil Moisture (\%) } \\
\text { Feekes } 5\end{array}$} \\
\hline & & \multicolumn{2}{|c|}{$0-15 \mathrm{~cm}$} & \multicolumn{2}{|c|}{$15-30 \mathrm{~cm}$} & \multicolumn{2}{|c|}{$30-45 \mathrm{~cm}$} & \multirow{2}{*}{$\frac{\text { Avg. } 0-45 \mathrm{~cm}}{\text { Mean }}$} \\
\hline & & Mean & SED & Mean & SED & Mean & SED & \\
\hline 1. & $0-29-37$ & 16.25 & 0.38 & 20.22 & 1.41 & 21.47 & 0.83 & 19.31 \\
\hline 2. & $45-29-37$ & 14.02 & 1.18 & 18.39 & 0.44 & 21.02 & 1.60 & 17.81 \\
\hline 3. & $90-29-37$ & 14.21 & 1.49 & 17.67 & 1.26 & 21.54 & 0.56 & 17.81 \\
\hline 4. & $135-29-37$ & 12.38 & 0.82 & 18.34 & 1.42 & 20.11 & 2.40 & 16.94 \\
\hline \multirow[t]{4}{*}{10.} & 0-0-0 & 16.41 & 0.93 & 20.33 & 1.19 & 20.01 & 1.29 & 18.92 \\
\hline & & \multicolumn{7}{|c|}{ Feekes 7} \\
\hline & & \multicolumn{2}{|c|}{$0-15 \mathrm{~cm}$} & \multicolumn{2}{|c|}{$15-30 \mathrm{~cm}$} & \multicolumn{2}{|c|}{$30-45 \mathrm{~cm}$} & Avg. $0-45 \mathrm{~cm}$ \\
\hline & & Mean & SED & Mean & SED & Mean & SED & Mean \\
\hline 1. & $0-29-37$ & 18.87 & 0.67 & 18.45 & 0.50 & 18.59 & 0.25 & 18.64 \\
\hline 2. & $45-29-37$ & 18.42 & 0.95 & 17.53 & 0.93 & 18.18 & 1.04 & 18.04 \\
\hline 3. & $90-29-37$ & 17.16 & 1.17 & 18.75 & 1.62 & 20.34 & 2.54 & 18.75 \\
\hline 4. & $135-29-37$ & 16.54 & 1.46 & 19.36 & 0.33 & 19.52 & 1.31 & 18.47 \\
\hline 10. & 0-0-0 & 17.82 & 0.76 & 18.72 & 0.89 & 18.05 & 0.48 & 18.20 \\
\hline
\end{tabular}

Mean-mean gravimetric moisture \% determined by averaging four cores.

SED— standard error of the difference between two equally replicated means, $=\sqrt{ } 2 \times$ $\mathrm{s}^{2} / \mathrm{n}$.

soil moisture and final grain yield is plausible. This is generally because the increased growth in the fertilized plots (treatments 2-4) would result in an increased demand for water and, as a result, more rapid depletion (Table 3).

\section{Soil Bulk Density, Resistance, and pH}

Soil bulk density $(0-15 \mathrm{~cm})$ is reported by treatment in Table 4 . Bulk-density values decreased with increasing applied $\mathrm{N}$. This result is consistent with results reported by Lal and Ahmadi (2000), who studied soils within the $1.2-1.4 \mathrm{~g} \mathrm{~cm}^{-3}$ range. Similarly, surface soil-bulk density values were negatively correlated with final grain yield $(r=-0.35)$. Soil resistance measured to a depth of 15 $\mathrm{cm}$ tended to be higher in those plots where $\mathrm{N}$ had been applied continuously over this 30-year experiment (Figure 1). However, there were many exceptions to this finding when evaluating single measurements under specific treatments 
Table 4

Response of bulk density $(0-15 \mathrm{~cm}), \mathrm{NH}_{4}-\mathrm{N}, \mathrm{NO}_{3}-\mathrm{N}$, total $\mathrm{N}$, organic $\mathrm{C}$, and $\mathrm{pH}$ as influenced by treatment in long-term fertility experiment \#222, Stillwater, OK, 2004

\begin{tabular}{|c|c|c|c|c|c|c|c|}
\hline & $\begin{array}{c}\text { Treatment } \\
\text { N-P-K } \\
\mathrm{kg} \mathrm{ha}^{-1}\end{array}$ & $\begin{array}{c}\text { Bulk } \\
\text { Density }\end{array}$ & $\begin{array}{c}\mathrm{NH}_{4}-\mathrm{N} \\
\mathrm{mg} \mathrm{kg}^{-1}\end{array}$ & $\begin{array}{c}\mathrm{NO}_{3}-\mathrm{N} \\
\mathrm{mg} \mathrm{kg}^{-1}\end{array}$ & $\begin{array}{l}\text { Total N } \\
\mathrm{g} \mathrm{kg}^{-1}\end{array}$ & $\begin{array}{c}\text { Organic C } \\
\mathrm{g} \mathrm{kg}^{-1}\end{array}$ & $\mathrm{pH}$ \\
\hline 1. & $0-29-37$ & 1.22 & 6.8 & 1.4 & 0.077 & 0.916 & 5.8 \\
\hline 2. & $45-29-37$ & 1.23 & 6.7 & 1.5 & 0.088 & 1.067 & 5.9 \\
\hline 3. & $90-29-37$ & 1.13 & 7.8 & 2.0 & 0.085 & 1.020 & 5.6 \\
\hline 4. & $135-29-37$ & 1.13 & 21.6 & 14.0 & 0.090 & 1.037 & 5.6 \\
\hline 10. & 0-0-0 & 1.21 & 6.3 & 2.0 & 0.071 & 0.827 & 5.9 \\
\hline SED & & 0.08 & 4.0 & 2.1 & 0.033 & 0.048 & 0.04 \\
\hline r & & -0.33 & 0.50 & 0.58 & 0.63 & 0.63 & -0.74 \\
\hline
\end{tabular}

$\mathrm{N}$, $\mathrm{P}$, and $\mathrm{K}$ applied preplant and incorporated as ammonium nitrate $(34 \% \mathrm{~N})$, triple super phosphate $(20 \% \mathrm{P})$, and potassium chloride ( $49 \% \mathrm{~K})$.

SED—-standard error of the difference between two equally replicated means, $=\sqrt{ } 2 \times$ $\mathrm{s}^{2} / \mathrm{n}$.

$\mathrm{r}$ - simple correlation coefficient for each variable versus final grain yield.

Soil resistance $(\mathrm{kPa})$

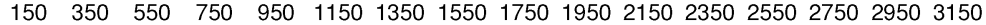

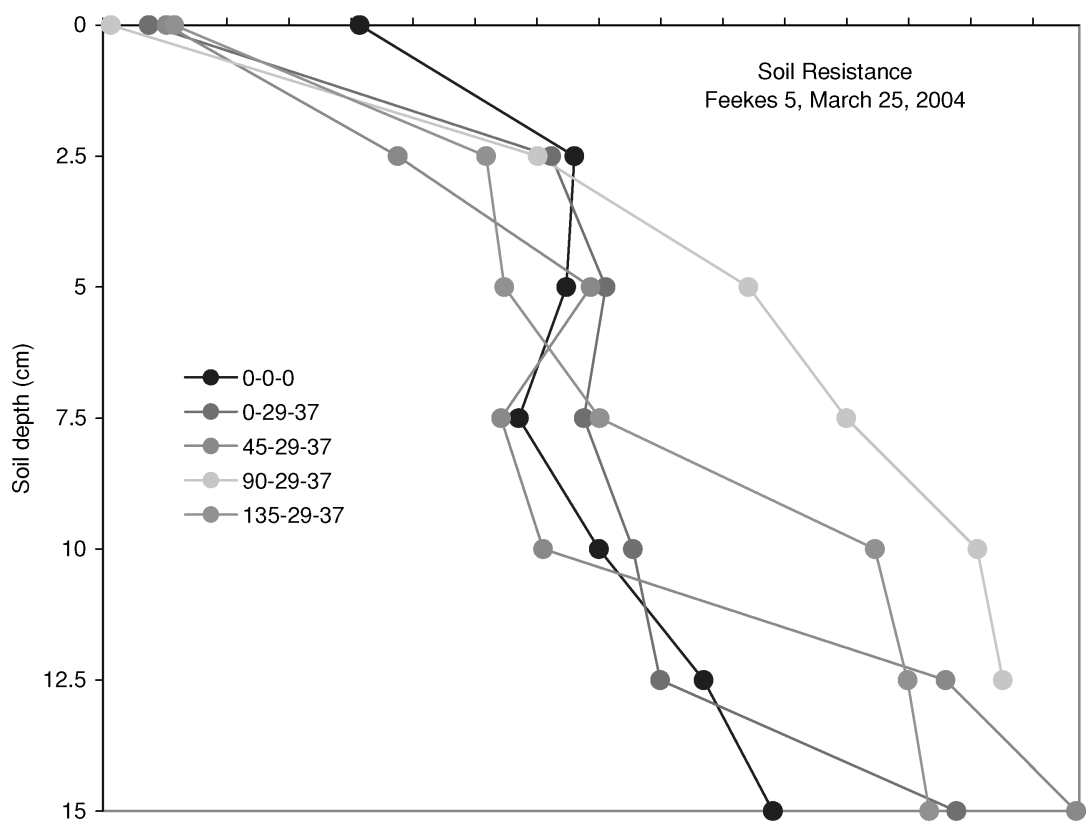

Figure 1. Soil resistance by depth as influenced by annually applied N-P-K ( $\left.\mathrm{kg} \mathrm{ha}^{-1}\right)$ in Experiment 222, Stillwater, OK. 
Table 5

Cumulative $\mathrm{N}$ mineralized in $120 \mathrm{~d}$ of aerobic incubation as influenced by treatment in experiment \#222, Stillwater, OK, 2004

\begin{tabular}{lcrrrrr}
\hline & $\begin{array}{c}\text { Treatment } \\
\mathrm{N}-\mathrm{P}-\mathrm{K} \\
\mathrm{kg} \mathrm{ha}^{-1}\end{array}$ & \multicolumn{4}{c}{ Total inorganic $\mathrm{N}\left(\mathrm{NH}_{4}-\mathrm{N}+\mathrm{NO}_{3}-\mathrm{N}\right) \mathrm{mg} \mathrm{kg}^{-1}$} \\
\cline { 3 - 7 } & Day 1 & Day 30 & Day 60 & Day 90 & Day 120 \\
\hline 1. & $0-29-37$ & 8.2 & 14.3 & 21.4 & 35.6 & 45.2 \\
2. & $45-29-37$ & 8.2 & 14.3 & 22.2 & 41.7 & 50.2 \\
3. & $90-29-37$ & 9.8 & 16.3 & 27.2 & 48.8 & 54.4 \\
4. & $135-29-37$ & 35.6 & 20.7 & 60.1 & 81.9 & 79.7 \\
10. & $0-0-0$ & 8.3 & 11.1 & 15.9 & 28.9 & 39.3 \\
SED & & 6.0 & 2.9 & 5.5 & 9.5 & 6.8 \\
\hline
\end{tabular}

(data not reported). Similar to observations for bulk density, soil $\mathrm{pH}$ decreased with increasing $\mathrm{N}$ applied (Table 4), and was highly correlated with final grain yield $(\mathrm{r}=-0.74)$. This result was expected considering that continuous $\mathrm{N}$ applications have led to lower $\mathrm{pH}$, but not to the extent where soil $\mathrm{pH}$ has had a negative influence on wheat-grain yield (lowest values at 5.6).

\section{Nitrogen Mineralization Potential}

Results from total inorganic $\mathrm{N}$ mineralized at 1, 30, 60, 90, and $120 \mathrm{~d}$ as a function of treatment are reported in Table 5. Total mineralized inorganic $\mathrm{N}$ was highly correlated with final grain yield, with the highest value found at $60 \mathrm{~d}(\mathrm{r}=$ $0.54,0.49,0.79,0.75$, and 0.64 , respectively). Nitrogen mineralized at 60 and $90 \mathrm{~d}$ was found to be highly correlated with NDVI at Feekes physiological growth stages 5 and 7 (all $r$ values $>0.57$ ). Similarly, $N$ mineralized at 60 and $90 \mathrm{~d}$ was highly correlated with chlorophyll meter readings collected at Feekes physiological growth stages 5 and 7 ( $\mathrm{r}$ values $>0.71$ ). Also, $\mathrm{N}$ mineralized at $90 \mathrm{~d}$ was highly correlated with plant height (Feekes 7 and Feekes 10, r > 0.74).

\section{Surface $\mathrm{NH}_{4}-\mathrm{N}$ and $\mathrm{NO}_{3}-\mathrm{N}$}

Surface soil $(0-15 \mathrm{~cm}) \mathrm{NH}_{4}-\mathrm{N}$ and $\mathrm{NO}_{3}-\mathrm{N}$ collected once in March (at Feekes physiological growth stage 5) were both highly correlated with final grain yield $(r>0.51)$. This result was expected as these long-term plots had received the same amount of $\mathrm{N}$ each year, and spanned a range of rates $(0$ to $135 \mathrm{~kg} \mathrm{~N}$ $\mathrm{ha}^{-1} \mathrm{yr}^{-1}$ ). As the annual $\mathrm{N}$ rate increased, so did surface $\mathrm{NH}_{4}-\mathrm{N}$ and $\mathrm{NO}_{3}-\mathrm{N}$ (Table 4). However, these quantities are dynamic in that the amounts depended on moisture and temperature; thus, a specific amount is not necessarily correlated with a specific yield level. 


\section{Organic Carbon and Total Nitrogen}

Surface soil organic $\mathrm{C}$ and total $\mathrm{N}$ determined via dry combustion was positively correlated with final grain yield $(\mathrm{r}>0.62)$. Organic $\mathrm{C}$ and total $\mathrm{N}$ were also highly correlated with NDVI sensor readings at Feekes physiological growth stages 5 and 7 ( $\mathrm{r}$ values all $>0.72$ ). Consistent with work by Davis et al. (2003) soil organic $\mathrm{C}$ and total $\mathrm{N}$ increased with increasing applied $\mathrm{N}$ (Table 4). In this long-term experiment, organic $\mathrm{C}$ would be expected to be correlated with final grain yield, especially when including plots that had not received $\mathrm{N}$ for this same period of time, and that would be subjected to increased $\mathrm{N}$ mining from the soil organic-matter component.

\section{Statistical Parameters}

The coefficient of variation from NDVI readings determined at Feekes physiological growth stages 5,7, and 10 was negatively correlated with final grain yield at all stages $(\mathrm{r}>-0.80)$. As the $\mathrm{CVs}$ increased, grain yields decreased (Table 2). In general, we would expect that CVs should not be correlated with yield in a large population of data. However, in this long-term trial, a negative and highly correlated relationship was expected, as applied $\mathrm{N}$ increased tillers and thus coverage, which would decrease the variability in NDVI sensor readings (Table 2). Also, as was expected, the CVs from NDVI sensor readings at Feekes physiological growth stages 5 and 7 were negatively correlated with NDVI readings $(\mathrm{r}>-0.87)$, further suggesting that as NDVI increased, cover increased and the number of soil (NDVI values $<0.20$ ) readings decreased, thus decreasing $\mathrm{CV}$. Coefficient of variation readings were also negatively correlated with number of tillers $(r>-0.86)$ at these same respective growth stages.

\section{Multiple Linear Regressions}

The stepwise variable selection using a significance level of 0.15 resulted in 11 predictor variables (Table 6), while a significance level of 0.1 resulted in selection of two variables. For the first selection scenario after fitting a regression model, those variables contributing an insignificant part of the variability were removed and a six-variable model was fitted. Interestingly, the predictor variables in this model were mostly plant measurements taken between Feekes physiological growth stages 5 and 7 . This result supports the previous findings by Lukina et al. (2001), who reported that in-season measurements such as NDVI were reliable for predicting final grain yield.

The second stepwise model selection removed all variables but leafchlorophyll content at Feekes physiological growth stage 7 and total $\mathrm{N}$ in soil as predictors of final grain yield, with an associated $\mathrm{R}^{2}$ of 0.94 . On the other 
Table 6

Identification of predictor variables and best linear-regression models for explaining variation in final grain yield in winter wheat

\begin{tabular}{llrr}
\hline $\begin{array}{l}\text { No. of } \\
\text { variables }\end{array}$ & Predictor variables in the model & $\mathrm{R}^{2}$ & $\mathrm{CV}$ \\
\hline 11 & TN, OC, NDVI_F5, NDVI_F7, NDVI_F10, SPAD_F7, & 0.99 & 6.5 \\
& HT_F7, PB, NO 3 , CV_F5, CV_F7 & & \\
6 & TN, NDVI_F7, Chl_F7, ht_F7, pb, CV_F7 & 0.98 & 7.6 \\
4 & TN, NDVIF7, Chl_F7, ht_F7 & 0.96 & 8.9 \\
3 & TN, NDVI_F7,Chl_F7 & 0.95 & 11.4 \\
2 & TN, Chl_F7 & 0.94 & 11.9 \\
1 & Chl_F7 & 0.87 & 19.5 \\
1 & NDVI_F7 & 0.78 & 23.0 \\
\hline
\end{tabular}

$\mathrm{TN}$ and $\mathrm{OC}$ - total soil $\mathrm{N}$ and organic carbon determined by dry combustion.

NDVI_F5, 7 and 10-normalized difference vegetative index sensed at Feekes 5, 7 and 10.

SPAD_F7-leaf chlorophyll content measured at Feekes 7.

HT_F7—plant height measured at Feekes 7.

$\mathrm{pb}$ - bulk density.

CV_F5 \& 7-NDVI coefficient of variation at Feekes 5 and 7.

hand, the best single predictor variable model was the one using leaf chlorophyll content at Feekes 7 , explaining $87 \%$ of the variability in grain yield explained by the full model containing 11 variables. The NDVI measured at Feekes 7 also explained about $77 \%$ of the variability in yield explained by the full model.

The four-, three-, and two-predictor variable models from the first selection scenario had very close $\mathrm{R}^{2}$, and any of the models can be used for prediction of final grain yield. Obviously, more variables in a model enable researchers to capture the variability in the predicted final grain yield better than few predictor variables. However, the models above clearly showed that most of the variability in final grain yield could be easily recovered by inclusion of at most four predictor variables. Therefore, NDVI, chlorophyll content, and height at Feekes physiological growth stage 7 , along with and total $\mathrm{N}$, could be used to reliably predict final grain yield of winter wheat.

\section{CONCLUSIONS}

Correlation and regression analyses results suggested that variables such as canopy temperature, $\mathrm{NH}_{4}-\mathrm{N}, \mathrm{NO}_{3}-\mathrm{N}$ and bulk density were poorly associated with final grain yield and were also not good predictors of final grain yield. Interestingly, mid-season measurements (Feekes 5 to 7) of NDVI, chlorophyll 
content, leaf color, $\mathrm{CV}$, and plant height were found to be strongly associated with final grain yield. Variables such as tillers per plant and canopy temperature had a strong association with final grain yield only at a specific growth stage, which narrows the prediction window as a function of growth stage. Both the correlation and regression analyses generally suggested that several variables can be used for predicting yield potential. It is also important to give attention to the limitations of each variable from biological, physical, and engineering perspectives. The linear multiple-regression equation results suggest that NDVI, chlorophyll content, plant height, and total $\mathrm{N}$ uptake are good predictors of final winter wheat grain yield and the literature review presented in this report also supports this conclusion.

\section{ACKNOWLEDGMENTS}

Contribution from the Oklahoma Agricultural Experiment Station.

\section{REFERENCES}

Arora, V. K., and P. R. Gijri. 1998. Evaluation of a crop growth-water balance model for analyzing wheat responses to climate and water-limited environments. Field Crop Research 59:213-224.

Blake, G. R., and K. H. Hartge. 1986. Bulk Density. In Methods of soil analysis, Part 1: Physical and mineralogical properties, $2^{\text {nd }}$ edition, ed. A. Klute, 363-382. Madison, WI: ASA and SSSA.

Brady, N. C., and R. R. Weil. 2002. The nature and properties of soils, $13^{\text {th }}$ edition. New York: Prentice Hall Publishing.

Bremner, J. M. 1965. Inorganic forms of nitrogen. Agronomy 9:1179-1237.

Chan, K. Y. 2002. Bulk density. In Encyclopedia of soil science, ed. R. Lal, 128-130. New York: Marcel Dekker.

Clawson, K. L., R. D. Jackson, and P. J. Pinter. 1989. Evaluating plant water stress with canopy temperature differences. Agronomy Journal 81:858864.

Conventry, D. R., D. K. Cann, H. D. Brooke, and T. G. Reeves. 1993. Influence of genotype, sowing date, and seeding rate on wheat development and yield. Australian Journal of Experimental Agriculture 33:751-757.

Cote, L., S. Brown, D. Pare, J. Fyles, and J. Bauhus. 2000. Dynamics of carbon and nitrogen mineralization in relation to stand type, stand age, and soil texture in the boreal mixedwood. Soil Biology and Biochemistry 32:10791090.

Davis, R. L., J. J. Patton, R. K. Teal, Y. Tang, M. T. Humphries, J. Mosali, K. Girma, J. W. Lawles, S. M. Moges, A. Malpati, J. Si, H. Zhang, S. Deng, G. V. Johnson, R. W. Mullen, and W. R. Raun. 2003. Nitrogen balance in the 
Magruder plots following 109 years in continuous winter wheat. Journal of Plant Nutrition 26:1561-1580.

Dinnes, D. L., D. L. Karlen, D. B. Jaynes, T. C. Kaspar, J. L. Hatfield, T. S. Colvin, and C. A. Cambardella. 2002. Nitrogen management strategies to reduce nitrate leaching on tile-drained Midwestern soils. Agronomy Journal 94:153-171.

Droogers, P., and J. Bouma. 1996. Biodynamic vs. conventional farming effects on soil structure expressed by simulated potential productivity. Soil Science Society of America Journal 60:1552-1558.

Drury, C. F., T. Q. Zhang, and B. D. Kay. 2003. The non-limiting and least limiting water ranges for soil nitrogen mineralization. Soil Science Society of America Journal 67:1388-1404.

Evans, G. 1991. Acidic soils in Australia. Canberra, Australia: Bureau of Rural Resources, Department of Primary Industries and Energy.

Filella, R. A., D. Ress, K. D. Sayre, Z. M. Lu, A. G. Condon, and A. L. Saavedra. 1995. Wheat yield progress associated with stomatical conductance. Crop Science 35:1400-1405.

Fisher, R. A., D. Ress, K. D. Sayre, Z. M. Lu, A. G. Condon, and A. L. Saavedra. 1998. Wheat yield progress associated with stomatical conductance. Crop Science 38:1467-1475.

Flowers, M., R. Weisz, and R. Heiniger. 2001. Remote sensing of winter wheat tiller density for early nitrogen application decisions. Agronomy Journal 93:783-789.

Flowers, M., R. Weisz, R. Heiniger, B. Tarleton, and A. Meijer. 2003. Field validation of a remote sensing technique for early nitrogen application decisions in wheat. Agronomy Journal 95:167-176.

Gee, G. W., and J. W. Bauder. 1986. Particle size analysis. In Methods of soil analysis, Part 1: Physical and mineralogical methods, $2^{\text {nd }}$ edition, ed. A. Klute, 383-411. Madison, WI: American Society of Agronomy.

Groffman, P. M. 1999. Carbon addition increases nitrogen availability in northern hardwood forest soils. Biology and Fertility of Soils 29:430433.

Heinemann, A. B., G. Hoogenboom, and B. Chojnicki. 2002. The impact of potential errors in rainfall observation on the simulation of crop growth, development and yield. Ecological Modelling 15:1-21.

Hoogenboom, G., J. W. Jones, P. W. Wilkens, W. D. Batchelor, W. T. Bowen, L. A. Hunt, N. B. Pickering, U. Singh, D. C. Godwin, B. Baer, K. J. Boote, J. T. Ritchie, and J. W. White. 1994. Crop Models. In Decision support system for agrotechnology transfer (DSSAT), Version 3, eds. G. Y. Tsuji, G. Uehara, and S. Balas, 95-244. Honolulu: University of Hawaii.

Huda, A. K. S. 1994. Management strategies to minimize climatic risk to wheat production in low rainfall areas of Southern Australia. Agricultural and Forest Meteorology 69:125-146. 
Hussain, F., K. F. Bronson, Y. Singh, B. Singh, and S. Peng. 2000. Use of chlorophyll meter sufficiency indices for nitrogen management of irrigated rice in Asia. Agronomy Journal 92:875-879.

Ishaq, M., A. Hassan, M. Saeed, M. Ibrahim, and R. Lal. 2001. Soil compaction effects on crops in Punjab, Pakistan. I. Soil physical properties and crop yield. Soil Tillage Research 59:57-65.

Johnson, A., M. Evans, and K. Wansink. 2001. Challenging sowing rates for wheat to achieve target plant densities. In Proceedings of the Australian Agronomy Conference, Australian Society of Agronomy, http://www. regional.org.au/au/asa/2001/p/10/Johnson. htm (accessed February 2004).

Jones, Jr., J.B. 2001. Laboratory guide for conducting soil tests and plant analysis. Boca Raton, Florida: CRC Press.

Karcher, D. E., and M. D. Richardson. 2003. Quantifying turfgrass color using digital image analysis. Crop Science 43:943-951.

Kutner, M. H., C. J. Nachtsheim, and J. Neter. 2004. Applied linear regression models, $4^{\text {th }}$ edition. New York: McGraw Hill.

Lal, R., and M. Ahmadi. 2000. Axle load and tillage effects on crop yield for two soils in central Ohio. Soil Tillage Research 54:111-119.

Lampurlanés, J., and C. Cantero-Martínez. 2003. Soil bulk density and penetration resistance under different tillage and crop management systems and their relationship with barley root growth. Agronomy Journal 95:526-536.

Little, T. M., and F. J. Hills. 1978. Agriculture expansion. New York: John Wiley.

Lukina, E. V., K. W. Freeman, K. J. Wynn, W. E. Thomason, R. W. Mullen, G. V. Johnson, R. L. Elliott, M. L. Stone, J. B. Solie, and W. R. Raun. 2001. Nitrogen fertilization optimization algorithm based on in-season estimates of yield and plant nitrogen uptake. Journal of Plant Nutrition 24:885-898.

Lukina, E. V., W. R. Raun, M. L. Stone, J. B. Solie, G. V. Johnson, H. L. Lees, J. M. LaRuffa, and S. B. Phillips. 2000. Effect of row spacing, growth stage, and nitrogen rate on spectral irradiance in winter wheat. Journal of Plant Nutrition 23:103-122.

Lukina, E. V., M. L. Stone, and W. R. Raun. 1999. Estimating vegetation coverage in wheat using digital images. Journal of Plant Nutrition 22:341-350.

Machado, S., E. D. Bynum, T. L. Archer, R. J. Lascano, L. T. Wilson, J. Bordovosky, E. Segarra, K. Bronson, D. M. Nesmith, and W. Xu. 2002. Spatial and temporal variability of corn growth and grain yield: Implications for site-specific farming. Crop Science 42:1564-1576.

Major, D. J., B. L. Blad, A. Bauer, J. L. Hatfield, K. G. Hubbard, E. T. Kanemasu, and R. J. Reginato. 1988. Winter wheat grain yield response to water and nitrogen on the North American great plains. Agricultural and Forest Meteorology 1988:141-149.

Malhi, S. S., M. Nyborg, and D.J. Heaney. 1992. Potential for nitrogen mineralization in central Alberta soils. Journal of Fertilizer Research 32:321325. 
Mallarino, A. P., E. S. Oyarzabal, and P. N. Hinz. 1999. Interpreting within-field relationships between crop yields and soil and plant variables using factor analysis. Precision Agriculture 1:15-25.

Mallows, C. L. 1973. Some comments on $C_{p}$. Technometrics 15:661-675.

McLeod, J. G., C. A. Campbell, Y. Gan, F. B. Dyck, and C. L. Vera. 1995. Seeding depth, rate and row spacing for winter wheat grown on stubble and chemical fallow in the semiarid prairies. Canadian Journal of Plant Science 76:207-214.

Millard, J. P., R. D. Jackson, R. C. Goettleman, and R. J. Reginato. 1978. Crop water-stress assessment using an airborne thermal scanner. $P E \& R S$ 44(1):77-85.

Munsell. 1988. Munsell book of color. Baltimore: MacBeth Division of Kollmorgen Instruments Corporation.

Ndegwa, P. M., and S. A. Thompson. 2000. Effects of C-to-N ratio on vermicomposting of biosolids. Bioresource Technology 75:7-12.

Nielson, D. C., and A. D. Halvorson. 1991. Nitrogen fertility influence on water stress and yield of winter wheat. Agronomy Journal 83:1065-1070.

Peterson, C. M., B. Klepper, and R. W. Rickman. 1982. Tiller development at the coleoptiler node in winter wheat. Agronomy Journal 74:781-784.

Peterson, T. A., T. M. Blackmer, D. D. Francis, and J. S. Schepers. 1993. Using a chlorophyll meter to improve N management, Nebguide G93-1171A. Lincoln, NE: Cooperative Extension Service, University of Nebraska.

Purcell, L. C. 2000. Soybean canopy coverage and light interception measurements using digital imagery. Crop Science 40:834-837.

Rashid, A. J., C. Stark, A. Tanveer, and T. Mustafa. 1999. Use of canopy temperature measurements as a screening tool for drought tolerance in spring wheat. Journal of Agronomy and Crop Science 182:231-237.

Rassmussen, P. E., C. L. Douglas, Jr., H. P. Collins, and S. L. Albrecht. 1998. Long-term cropping system effects in mineralizable nitrogen in soil. Journal of Soil Biology and Biochemistry 30:1829-1837.

Raun, W. R., and G. V. Johnson. 2001. Improving nitrogen use efficiency for cereal production. Agronomy Journal. 93:131-138.

Raun, W. R., G. V. Johnson, M. L. Stone, J. B. Solie, E. V. Lukina, W. E. Thomason, and J. S. Schepers. 2001. In-season prediction of potential grain yield in winter wheat using canopy reflectance. Agronomy Journal 93:131-138.

Raun, W. R., J. B. Solie, G. V. Johnson, M. L. Stone, R. W. Mullen, K. W. Freeman, W. E. Thomason, and E. V. Lukina. 2002. Improving nitrogen use efficiency in cereal grain production with optical sensing and variable rate application. Agronomy Journal 94:815-820.

Raun, W. R., J. B. Solie, G. V. Johnson, M. L. Stone, R. W. Whitney, H. L. Lees, H. Sembiring, and S. B. Phillips. 1998. Micro-variability in soil test, plant nutrient, and yield parameters in bermudagrass. Soil Science Society of America Journal 62:683-690. 
Ringuelet, A., and O. A. Bachmeier. 2002. Kinetics of soil nitrogen mineralization from undisturbed and disturbed soil. Communications in Soil Science and Plant Analysis 33:3703-3721.

Risasi, E. L., G. Tian, B. T. Khang, and E. E. Opuwaribo. 1999. Nitrogen mineralization of roots of maize and selected woody species. Communications in Soil Science and Plant Analysis 30(9\&10):1431-1447.

Robinson, J. B., D. M. Freebairn, J. P. Dimes, R. C. Dalal, G. A. Thomas, and E. J. Weston. 1999. Modeling wheat production from low-rainfall farming systems in northern Australia. Environmental International 25(6-7):861870.

Rovira, P., and V. R. Vallejo. 2002. Mineralization of carbon and nitrogen from plant debris size and depth of burial. Soil Biology and Biochemistry 34:327-339.

Rurnett, V. F., J. H. Schneider, and F. W. Dempsey. 2003. Effect of seeding rate on organic wheat production and ryegrass density in northeast Victoria. In Proceedings of the 2003 Australian Agronomy Conference, Australian Society of Agronomy, http://www.regional.org.au/au/asa/2003 (accessed February 2004).

Scharf, P. C., and J. A. Lory. 2002. Calibrating corn color from aerial photographs to predict sidedress nitrogen need. Agronomy Journal 94:397404.

Schepers, J. S., and D. D. Francis. 1998. Precision agriculture: What's in our future. Communications in Soil Science and Plant Analysis 29:1463-1469.

Schepers, J. S., D. D. Francis, and M. T. Thompson. 1989. Simultaneous determination of total $\mathrm{C}$, total $\mathrm{N}$, and ${ }^{15} \mathrm{~N}$ on soil and plant material. Communications in Soil Science and Plant Analysis 20:949-959.

Schepers, J. S., D. D. Francis, M. Vigil, and F. E. Below. 1992. Comparison of corn leaf nitrogen concentration and chlorophyll meter readings. Communications in Soil Science and Plant Analysis 23:2173-2187.

Singh, B., Y. Singh, J. K. Ladha, K. F. Bronson, V. Balasubramanian, J. Singh, and C. S. Khind. 2002. Chlorophyll meter- and leaf color chart-based nitrogen management for rice and wheat in northeastern India. Agronomy Journal 94:821-829.

Smith, J. L., R. R. Schnobel, B. L. McNeal, and G. S. Campbell. 1980. Potential errors in the first order model for estimating soil nitrogen mineralization potentials. Soil Science Society of America Journal 44:996-1000.

Solie, J. B., W. R. Raun, and M. L. Stone. 2000. Submeter spatial variability of selected soil and plant variables. Soil Science Society of America Journal 63:1724-1733

Solie, J. B., W. R. Raun, R. W. Whitney, M. L. Stone, and J. D. Ringer. 1996. Optical sensor based field element size and sensing strategy for nitrogen application. Transactions of ASAE 39(6):1983-1992.

Sparks, D. L. 2003. Environmental soil chemistry, $2^{\text {nd }}$ edition. New York: Academic Press. 
Stanford, J. L., and S. J. Smith. 1972. Nitrogen mineralization potentials of soils. Soil Science Society of America Proceedings 36:465-472.

Steel, R. G. D., J. H. Torrie, and D. A. Dickey. 1997. Principles and procedures of statistics: A biometrical approach, $3^{\text {rd }}$ edition. New York: McGraw-Hill.

Stockton, R. D., E. G. Krenzer, Jr., H. Solie, and M. E. Payton. 1996. Stand establishment in winter wheat in Oklahoma: A survey. Journal of Production Agriculture 9:571-575.

Stone, M. L., J. B. Solie, W. R. Raun, R. W. Whitney, S. L. Taylor, and J. D. Ringer. 1996. Use of spectral radiance for correcting in-season fertilizer nitrogen deficiencies in winter wheat. Transactions of ASAE 39(5):16231631.

Stougaard, R. N., and Q. Xue. 2003. Spring wheat seed size and seeding rate effects on yield loss due to wild oat (Avena fatua) interference. Weed Science 52:133-141.

Sylvia, D. M., J. J. Fuhrmann, P. G. Hartell, and D. A. Zuberer. 1999. Principles and applications of soil microbiolog. Upper Saddle River, New Jersey: Prentice Hall.

Taylor, S. L., G. V. Johnson, and W. R. Raun. 1997. A field exercise to acquaint students with soil testing as a measure of soil fertility status and field variability. Journal of Natural Resources and Life Sciences Education 26:132-135.

Troeh, F. R., and L. M. Thompson. 1993. Soils and fertility, $5^{\text {th }}$ edition. New York: Oxford University Press.

Varvel, G. E., D. D. Francis, and J. S. Schepers. 1997. Ability for in-season correction of nitrogen deficiency in corn using chlorophyll meter. Soil Science Society of America Journal 159:233-1239.

Vigil, M. F., and D. E. Kissel. 1991. Equations for estimating the amount of nitrogen mineralized from crop residues. Soil Science Society of America Journal 55:757-761.

Walley, F., T. Yates, J. W. van Groenigen, and C. van Kessel. 2002. Relationships between soil nitrogen availability indices, yield, and nitrogen accumulation of wheat. Soil Science Society of America Journal 66:1549-1561.

Washmon, C. N., J. B. Solie, W. R. Raun, and D.D. Itenfisu. 2002. Within field variability in wheat grain yields over nine years in Oklahoma. Journal of Plant Nutrition 25:2655-2662.

Weisz, R. W., C. R. Crozier, and R. W. Heiniger. 2001. Optimizing nitrogen application timing in no-till soft red winter wheat. A gronomy Journal 92:435442.

Wood, C. W., D. W. Reeves, R. R. Duffield, and K. L. Edmisten. 1992. Field chlorophyll measurements for evaluation of corn nitrogen status. Journal of Plant Nutrition 15:487-500.

Yang, W. H., S. Peng, J. Huang, A. L. Sanico, R. J. Buresh, and C. Witt. 2003. Using leaf color charts to estimate leaf nitrogen status. Agronomy Journal 95:212-217. 